\title{
Adaptation of Mindfulness in Parenting Questionnaire (MIPQ) for parents of children aged 2-12 years
}

\author{
Zulfa Febriani, ${ }^{1 *}$ Retno Budi Setyowati, ${ }^{2}$ Dewi Kumalasari, ${ }^{1}$ Endang Fourianalistyawati ${ }^{3}$ \\ ${ }^{1}$ Faculty of Psychology, Universitas YARSI, Jakarta - Indonesia, ${ }^{2}$ Faculty of Psychology, Universitas Persada \\ Indonesia Y.A.I., Jakarta - Indonesia, ${ }^{3}$ School of Human Ecology, University of Wisconsin, Madison - United \\ States
}

\begin{abstract}
Mindful parenting intervention programs and characteristics can support positive parenting conditions and have an impact on children's psychosocial development. However, the measurement of mindful parenting has not been widely developed, although one example is the Mindfulness in Parenting Questionnaire (MIPQ) scale, which has good psychological properties and has been validated in several countries. This study aims to obtain evidence of the validity of the interpretation of the Indonesian version of the MIPQ scale (MIPQ-Ind) amongsta population of parents with children aged $2-12$. The participants were 822 parents (268 fathers and 554 mothers) who live in Jakarta, Indonesia. The results, based on the use of the split sample technique and EFA and CFA tests, show that the MIPQ-Ind has two valid factors, as indicated by the index $2 / \mathrm{df}=2.8, \mathrm{CFI}=0.9, \mathrm{GFI}=0.96, \mathrm{RMSEA}=0.06$ and $\mathrm{RMSR}=0.04$. The internal structure validity is 0.913 for the 'being in the moment with child' (BMC) factor and 0.906 for the mindful discipline (MD) factor. The study shows that the MIPQInd was able to measure mindful parenting in the population of parents with children aged 2-12 in Indonesia.
\end{abstract}

Keywords: mindful parenting; mindfulness in parenting questionnaire; parenting

Abstrak: Program intervensi mindful parenting maupun karakter mindful parenting dapat mendukung keadaan pengasuhan yang positif dan berdampak pada perkembangan psikososial anak. Meski demikian, pengukuran terhadap mindful parenting belum banyak dikembangkan. Skala Mindfulness in Parenting Questionnaire (MIPQ adalah skala yang dikembangkan dan memiliki properti psikologis yang baik dan telah divalidasi di beberapa negara. Penelitian ini bertujuan untuk menemukan bukti validitas interpretasi skor MIPQ versi bahasa Indonesia (MIPQ-Ind) pada populasi orang tua dengan anak usia 2-12 tahun. Partisipan berjumlah 822 orang tua (268 ayah dan $554 \mathrm{ibu}$ ) yang tinggal di Jakarta. Hasil penelitian dengan teknik split sampel menggunakan uji EFA dan CFA menunjukkan bahwa MIPQ-Ind memiliki dua faktor yang valid yang ditunjukkan dengan indeks $\chi 2 / \mathrm{df}=2,8, \mathrm{CFI}=0,9, \mathrm{GFI}=0,96, \mathrm{RMSEA}=$ 0,06 dan RMSR=0,04. Validitas struktur internal sebesar 0,913 untuk faktor being in the moment with child (BMC) dan 0,906 pada faktor mindful discipline (MD). Penelitian ini menunjukkan bahwa MIPQ-Ind dapat mengukur mindful parenting pada populasi orang tua dari anak usia 2-12 tahun di Indonesia.

Kata Kunci: mindful parenting; mindfulness in parenting questionnaire; pengasuhan

"Corresponding Author: Zulfa Febriani (zulfa.febriani@yarsi.ac.id), Faculty of Psychology, Universitas YARSI, Jl. Let. Jend. Soeprapto Kav. 13 Cempaka Putih Timur, Cempaka Putih, Jakarta Pusat, Jakarta 10510 - Indonesia. 


\section{Introduction}

Good parenting is important for children's growth and development. The ability of parents to perceive signals from their infants and respond appropriately to these indicates good sensitivity and responsiveness. It is the key to parenting (Ainsworth et al., 2015). The combination of the sensitivity and responsiveness of parents appears in two important components of parenting, namely control and responsiveness. Control refers to the demands, supervision, and discipline that parents impose on children to mature. At the same time, responsiveness is related to the caring behavior and support from parents, which helps children become independent and have good selfregulation (Bornstein \& Bornstein, 2014).

The ability of parents to perform good parenting is influenced by several factors, including fatigue and parenting stress (Cooklin et al., 2012; Neece et al., 2012; Waylen \& StewartBrown, 2010), life background, parental culture and environment, marital conflict, and the characteristics of the children themselves (Bronfenbrenner, 1979). The results of most related studies show that depression or the mother's emotional state has the most influence on the sensitivity and quality of early parenting (Ciciolla et al., 2014; Razza \& Raymond, 2013; Waylen \& Stewart-Brown, 2010). However, fathers also play a role in children's behavior problems (Calzada et al., 2004). Therefore, it is very important to pay attention to parents' psychological state, especially those who still have small children.

Several studies have shown that parents' stress and emotional state in parenting can be improved by mindfulness programs or interventions in parenting or mindful parenting. Duncan,
Coatsworth, and Greenberg (2009a) explain that mindful parenting is an extension of the concept of mindfulness originating from Kabat-Zinn, namely the awareness that arises from paying attention to the current moment, with purpose and without judgment, in the context of parents' interactions with their children. Mindful parenting consists of the dimensions of listening with full attention, the non-judgmental acceptance of the self and child, the emotional awareness of the self and child, self-regulation in the parenting relationship, and compassion for the self and child.

Mindful parenting programs are beneficial for both fathers and mothers and those with small children and teenagers. Parents who participate in the program experience reduced parenting stress are better at cooperating with their children, and develop an authoritative parenting style (Bögels, Hellemans, van Deursen, Römer, \& van der Meulen, 2014), which affect parent-child relationships, child self-management, and parental well-being (Coatsworth et al., 2015; Reynolds, 2003; Singh et al., 2007). They also improve emotional regulation and the ability to cope with stress related to family circumstances (Duncan, Coatsworth, \& Greenberg, 2009b). Practicing mindful parenting, especially high nonjudgmental acceptance, is associated with lower depression and anxiety in adolescents, while parents who practice low mindful parenting usually have symptoms of depression and anxiety (Geurtzen, Scholte, Engels, Tak, \& van Zundert, 2015).

Research without an intervention model has also shown that mindful parenting is significantly associated with lower parenting stress, with an authoritative parenting style, and contrasts with 
an authoritarian and permissive parenting style (Gouveia, Carona, Canavarro, \& Moreira, 2016; Williams \& Wahler, 2010) low parental anxiety, child and parent attachment and good child welfare (Medeiros et al., 2016; Parent et al., 2016)

Although intervention programs and research have been developed, the measurement of mindful parenting has not been widely established. One scale developed for measuring mindful parenting is the Interpersonal Mindfulness in Parenting (IMP) scale of Duncan (2007) for parents of children aged 10-14. The scale consists of four dimensions: present-centered attention, presentcentered emotional awareness, low reactivity, and non-judgemental acceptance. Each comprises two items, with responses consisting of five values, from 'never appropriate' (1) to 'always appropriate' (5). The scale has good psychological properties (Cronbach's alpha in the range 0.45$0.66, \mathrm{CFI}=0.97$, RMSEA $=0.05$ ).

The IMP scale was validated in the Netherlands by de Bruin et al. (2014) on 899 mothers of children aged 12-15. They added IMP items after the approval of Duncan. The Dutch IMP has 29 items and consists of six dimensions, namely: (1) listening with full attention; (2) compassion for self and child; (3) non-judgmental acceptance of parental functioning; (4) emotional non-reactivity in parenting; (5) emotional awareness of the child; and (6) emotional awareness of the self. The IMP-Dutch scale also has good validity (Cronbach's alpha=0.54-0.83, RMSEA $=0.054, \mathrm{CFI}=0.96, \mathrm{SRMR}=0.089$ ). It also has a significant and negative correlation with the Parenting Scale, which measures dysfunctional parenting styles; is positively related to the quality-of-life domain (WHOQOL-BREF) apart from physical health; and is also related to the
Five Facet Mindfulness Questionnaire (FFMQ) scale.

The IMP scale developed by Duncan (2007) and adapted by de Bruin et al. (2014) cannot be applied to all parents, fathers, parents of younger children or older adolescents, parents who do not have clinical risk, or to a diverse population. Its psychometric properties have not been studied in those populations (McCaffrey, 2015; McCaffrey et al., 2017). To accomplish the need of applicability of mindful parenting scale to various populations of parents, McCaffrey (2015) and McCaffrey, Reitman, and Black (2017) developed the Mindfulness in Parenting Questionnaire (MIPQ) using the Item Response Theory (IRT) approach. The items in the MIPQ were developed from expert opinion and literature studies in the fields of mindfulness and mindful parenting and other related fields. The readability test interview resulted in 61 MIPQ items. The MIPQ was tested on 203 parents of children aged 2-16 years with fairly diverse races, social classes, and educational backgrounds. The results show that the MIPQ consists of two dimensions. The first of these is mindful discipline (MD), which focuses on parents, and includes non-reactivity in parenting, parenting awareness, and goal-focused parenting, with 15 items. The second dimension refers to being in the moment with the child (BMC), which focuses on children, and includes presentcentered attention, empathic understanding, and acceptance, with a total of 13 items.

The MIPQ scale was tested on 380 male and female parents of children aged 3-18 in Istanbul, Turkey (Gördesli et al., 2018). The CFA on this scale showed a good fit model in the one-factor and two-factor models, without including items $4,5,18$, and 19 as they had a significant error variance, meaning the number of items tested 
was only 24. The MIPQ-Turkey also had good internal consistency and a significant positive correlation with MAAS and the Parent-Child Communication Scales (PCCS). It was also adapted into Spanish (MIPQ-S), showing a good two-factor model, good reliability, and a significant correlation with dispositional mindfulness, positive parenting, child depression, and child resilience (Orue et al., 2020). Another version was adapted into Chinese (MIPQ-C), which also showed a good two-factor model, good reliability, a significant relationship with MAAS, IMP, authoritative parenting of PSDQ-short version, and a significant negative relationship with authoritarian and permissive parenting (Wu et al., 2019).

The MIPQ scale has never been tested psychometrically in diverse populations of Indonesia. However, approaches to and research on mindful parenting are starting to be widely conducted in the country, especially on parents with pre-school and school-age children (Dahlan, 2016; Gani \& Kumalasari, 2019; Rosyada \& Ramadhianti, 2019; Saraswati \& Febriani, 2018; Sofyan, 2019; Utami et al., 2020; Zaenab \& Indryanai, 2020). This research aims to establish whether the Indonesian version of the MIPQ (MIPQ-Ind) displays good validity after being used in parents of children aged 2-12 years in Indonesia.

\section{Methods}

First, the researcher contacted McCaffrey by email for permission to adapt the MIPQ. It was then translated into Indonesian by a sworn translator. The translation suitability was checked with the original measurement instrument, and a back-translation was then made. The translation results were analyzed through an expert judgment process by two lecturers who were researchers in children and families. The research team discussed the feedback from these experts and then conducted a readability test on five parents.

MIPQ-Ind was then tested on 822 people consisting of 268 fathers and 554 mothers who lived in Jakarta. The participants were chosen by accidental sampling. The average age of the participants was 34.08 years old. Most of them were high school graduates (37.23\%) and undergraduates (34.18\%). Most of the participants had two children (34.8\%); 75.08\% of these were pre-school (2-6 years), and the remainder school-age (7-12 years).

The construct validity was tested using exploratory factor analysis (EFA) and confirmatory factor analysis (CFA) by dividing the sample into two randomly. The item reliability was also analyzed using the alpha-Cronbach reliability technique, and JASP 12.2.0 software to perform the statistical calculations.

The EFA analysis was performed on 411 individuals (140 fathers and 271 mothers) with a mean age of 34.5 and with the mean age of their children 5.7 years. Most of the parents were undergraduates (36.5\%) and high school (34.8\%) graduates. CFA analysis was also performed on 411 parents (128 fathers, 283 mothers), the average age of whom was 33.48, and with an average age of their children of 5.5 years.

\section{Results}

Exploratory Factor Analysis (EFA) Test

In the EFA analysis, oblique promax rotation was performed because MIPQ's dimensions had a fairly strong correlation ( $\mathrm{r}=67$ ) on the original 
measuring instrument. The overall MSA value using the Kaiser-Meyer-Olkin Test was 0.950, and the Bartlett test was significant $(\mathrm{p}<.001)$. The scree plot graph in Figure 1 shows that MIPQ-Ind has two factors with eigenvalues $>1$ and its items have a factor loading of 0.3 and above. The correlation between factors is also quite strong $(\mathrm{r}=$.788). However, items BMC10 and MD11 have cross-loading in both factors. Items BMC12 and BMC13 contain factor loadings in the second factor, even though they are original items from the first factor. Items MD5, MD8, MD13, and MD15 also have a factor loading in factor 1, even though they are factor 2 items based on the original measuring instrument. Item MD14 does not contain factor loadings in either factor 1 or 2 . Each factor's loading level can be seen in Table 1.

Cross loading on items with unsatisfactory values, those that have very low loading, or loading on factors that are different from the original theory indicate that the items in each factor are less able to explain the variance in the construct. This can contribute to the value of the factor variance, as indicated by the total variance of these two factors of $41.7 \%$ in the model. Factor 1 contributed $22.9 \%$, and factor $218.8 \%$.

Item Reliability Analysis and Scale

Scale reliability analysis was conducted for each dimension and the overall scale with the Cronbach's alpha reliability test. Each reliability index can be seen in table 2. Overall, the MIPQ-Ind scale had Cronbach's alpha .941, with an item correlation total scale ranging from .452 to .651 . Based on the dimensions, each factor had a good Cronbach's alpha (factors 1 and 2 have a value of .898). Item correlation with total dimensions ranged from .470 to .666 for factor 1 , and .468 to .664 for factor 2 . The test reliability coefficient and item correlation with good total dimensions indicated that all the items had good consistency in measuring the mindfulness in parenting constructs.

\section{Figure 1}

Scree Plot

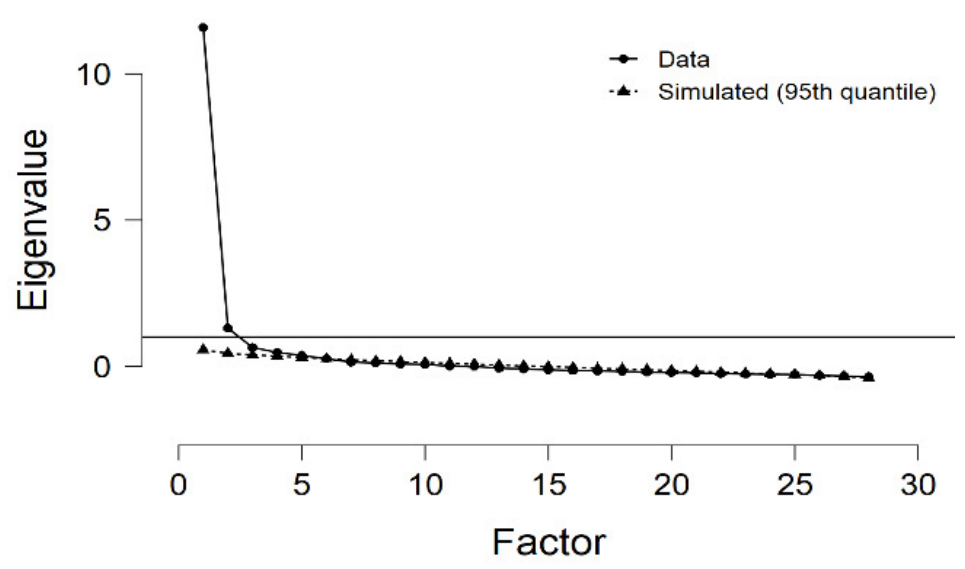


Table 1

Factor Loadings from EFA Test

\begin{tabular}{|c|c|c|}
\hline & Factor 1 & Factor 2 \\
\hline BMC1 & 0.397 & \\
\hline BMC2 & 0.675 & \\
\hline ВMC3 & 0.809 & \\
\hline BMC4 & 0.805 & \\
\hline BMC5 & 0.804 & \\
\hline BMC6 & 0.758 & \\
\hline BMC7 & 0.756 & \\
\hline BMC8 & 0.483 & \\
\hline BMC9 & 0.488 & \\
\hline BMC10 & 0.362 & 0.332 \\
\hline BMC11 & 0.489 & \\
\hline BMC12 & & 0.443 \\
\hline BMC13 & & 0.321 \\
\hline MD1 & & 0.809 \\
\hline MD2 & & 0.867 \\
\hline MD3 & & 0.630 \\
\hline MD4 & & 0.741 \\
\hline MD5 & 0.528 & \\
\hline MD6 & & 0.761 \\
\hline MD7 & & 0.602 \\
\hline MD8 & 0.450 & \\
\hline MD9 & & 0.408 \\
\hline MD10 & & 0.531 \\
\hline MD11 & 0.328 & 0.333 \\
\hline MD12 & & 0.395 \\
\hline MD13 & 0.457 & \\
\hline \multicolumn{3}{|l|}{ MD14 } \\
\hline MD15 & 0.539 & \\
\hline Variants & $22,9 \%$ & $18,8 \%$ \\
\hline
\end{tabular}

Confirmatory Factor Analysis (CFA) Test

The results of the first-order CFA test showed that the two-factor model did not fit, with a value of $\chi 2 / \mathrm{df}=3.6, \mathrm{GFI}=.94, \mathrm{CFI}=.82, \mathrm{RMSEA}=.08$, $\mathrm{RMSR}=.06$. The covariance between factors is quite high, at 0.841 , and the factor loadings from 0.361 to .650 . Table 3 shows the items and factor loadings from MIPQ-Ind.
Items with a factor loading $<0.5$ were excluded, namely BMC12, BMC13, MD1, MD8, MD10, MD14. In addition, there were high modification indices for the covariance of the error terms of MD3 and MD4, BMC4 and BMC5 so we modified them by adding a relationship on the covariance errors. In this way, a better fit model was obtained, as shown in Table 4. 
After obtaining items with satisfactory factor loadings, construct reliability (CR) was calculated, as obtained from the comparison between the squared sum of factor loadings (Li) for each construct and the sum of error variances $\left(e_{i}\right)$ for a construct, or with the formula:

$$
\mathrm{CR}=\frac{\left(\sum_{i=1}^{n} L_{i}\right)^{2}}{\left(\sum_{i=1}^{n} L_{i}\right)^{2}+\left(\sum_{i=1}^{n} e_{i}\right)}
$$

Based on the formula, the dimension CR values are .913 for BMC and .906 for MD. Therefore, it can be said that each dimension of the MIPQ-Ind scale has good internal validity. The CR values and each final item factor loading can be seen in Table 5 .

Table 2

Item's Reliability for 1 Factor and 2 Factors Solution

\begin{tabular}{|c|c|c|c|}
\hline No & Items & 1 factor & 2 Factors \\
\hline 1 & BIMC1 & 0.580 & 0.565 \\
\hline 2 & BIMC2 & 0.593 & 0.618 \\
\hline 3 & BIMC3 & 0.507 & 0.564 \\
\hline 4 & BIMC4 & 0.572 & 0.619 \\
\hline 5 & BIMC5 & 0.638 & 0.666 \\
\hline 6 & BIMC6 & 0.581 & 0.604 \\
\hline 7 & BIMC7 & 0.632 & 0.657 \\
\hline 8 & BIMC8 & 0.636 & 0.635 \\
\hline 9 & BIMC9 & 0.651 & 0.652 \\
\hline 10 & BIMC10 & 0.622 & 0.591 \\
\hline 11 & BIMC11 & 0.651 & 0.635 \\
\hline 12 & BIMC12 & 0.582 & 0.526 \\
\hline 13 & $\mathrm{BMC13}$ & 0.491 & 0.470 \\
\hline 14 & MD1 & 0.479 & 0.522 \\
\hline 15 & MD2 & 0.538 & 0.585 \\
\hline 16 & MD3 & 0.588 & 0.621 \\
\hline 17 & MD4 & 0.626 & 0.664 \\
\hline 18 & MD5 & 0.623 & 0.579 \\
\hline 19 & MD6 & 0.548 & 0.600 \\
\hline 20 & MD7 & 0.614 & 0.635 \\
\hline 21 & MD8 & 0.568 & 0.527 \\
\hline 22 & MD9 & 0.530 & 0.545 \\
\hline 23 & MD10 & 0.641 & 0.622 \\
\hline 24 & MD11 & 0.597 & 0.553 \\
\hline 25 & MD12 & 0.604 & 0.590 \\
\hline 26 & MD13 & 0.649 & 0.624 \\
\hline 27 & MD14 & 0.452 & 0.468 \\
\hline 28 & MD15 & 0.578 & 0.509 \\
\hline
\end{tabular}


Table 3

Factor Loadings from CFA Test

\begin{tabular}{|c|c|c|c|}
\hline Factor & & Items & $\lambda$ \\
\hline \multirow[t]{13}{*}{ Factor 1} & BIMC1 & $\begin{array}{l}\text { Cermat mendengarkan dan menyimak anak Anda saat kalian } \\
\text { berdua sedang berbicara }\end{array}$ & 0.516 \\
\hline & BIMC2 & $\begin{array}{l}\text { Secara aktif kembali memperhatikan anak Anda saat Anda } \\
\text { menyadari bahwa Anda telah teralihkan dari memperhatikan anak } \\
\text { Anda }\end{array}$ & 0.562 \\
\hline & BIMC3 & $\begin{array}{l}\text { Dapat menceritakan apa yang dipikirkan anak Anda, bahkan saat } \\
\text { mereka tidak memberi tahu Anda }\end{array}$ & 0.536 \\
\hline & BIMC4 & $\begin{array}{l}\text { Bisa menceritakan bagaimana perasaan anak Anda dengan cara } \\
\text { melihat mereka }\end{array}$ & 0.500 \\
\hline & BIMC5 & $\begin{array}{l}\text { Menyadari saat anak Anda "mengalami suatu masalah" melalui } \\
\text { perilaku mereka }\end{array}$ & 0.556 \\
\hline & BIMC6 & $\begin{array}{l}\text { Secara akurat memprediksi sebelumnya bagaimana anak Anda } \\
\text { akan bereaksi terhadap suatu situasi }\end{array}$ & 0.532 \\
\hline & BIMC7 & Memperhatikan bagaimana emosi Anda mempengaruhi anak Anda & 0.586 \\
\hline & BIMC8 & Merasa "selaras" dengan perasaan anak Anda & 0.602 \\
\hline & BIMC9 & Memperhatikan bagaimana anak Anda menanggapi perilaku Anda & 0.597 \\
\hline & BIMC10 & Memahami alasan anak Anda atas perilaku mereka & 0.577 \\
\hline & BIMC11 & $\begin{array}{l}\text { Memahami mengapa anak Anda bertindak seperti yang mereka } \\
\text { tunjukkan }\end{array}$ & 0.650 \\
\hline & BIMC12 & Bersenang-senang dan bertingkah lucu dengan anak Anda & 0.484 \\
\hline & BMC13 & Menerima anak Anda apa adanya & 0.361 \\
\hline \multirow[t]{15}{*}{ Factor 2} & MD1 & $\begin{array}{l}\text { Yakin bahwa cara Anda mengasuh anak sesuai dengan praktik } \\
\text { pengasuhan terbaik }\end{array}$ & 0.491 \\
\hline & MD2 & $\begin{array}{l}\text { Merasa percaya diri dengan kemampuan Anda untuk menangani } \\
\text { situasi pengasuhan yang sulit }\end{array}$ & 0.535 \\
\hline & MD3 & $\begin{array}{l}\text { Mempertimbangkan perasaan Anda sebelum menegakkan aturan } \\
\text { pada anak Anda }\end{array}$ & 0.518 \\
\hline & MD4 & $\begin{array}{l}\text { Mempertimbangkan perasaan anak Anda sebelum menegakkan } \\
\text { aturan pada anak Anda }\end{array}$ & 0.631 \\
\hline & MD5 & Memperhatikan kapan perilaku anak Anda membuat Anda kesal & 0.519 \\
\hline & MD6 & Bisa menenangkan diri saat anak Anda membuat Anda kesal & 0.628 \\
\hline & MD7 & $\begin{array}{l}\text { Memperhatikan pemikiran Anda tentang perilaku anak Anda } \\
\text { sebelum merespon perilaku anak Anda tersebut }\end{array}$ & 0.628 \\
\hline & MD8 & $\begin{array}{l}\text { Memberi tahu anak anda ketika mereka melakukan sesuatu yang } \\
\text { mengganggu Anda }\end{array}$ & 0.483 \\
\hline & MD9 & $\begin{array}{l}\text { Mengambil waktu sejenak untuk berpikir sebelum menghukum } \\
\text { anak Anda }\end{array}$ & 0.578 \\
\hline & MD10 & $\begin{array}{l}\text { Memilih untuk melakukan apa yang terbaik untuk masa depan } \\
\text { anak Anda, meskipun ada hal lain yang lebih mudah }\end{array}$ & 0.491 \\
\hline & MD11 & Menanyakan pendapat anak Anda & 0.549 \\
\hline & MD12 & $\begin{array}{l}\text { Meluangkan waktu untuk memikirkan pengasuhan yang Anda } \\
\text { lakukan }\end{array}$ & 0.584 \\
\hline & MD13 & $\begin{array}{l}\text { Mempertimbangkan beberapa alasan mengapa anak Anda } \\
\text { berperilaku seperti yang dia tunjukkan }\end{array}$ & 0.609 \\
\hline & MD14 & $\begin{array}{l}\text { Mencoba memperlambat respon Anda terhadap anak untuk } \\
\text { mencapai tujuan Anda sebagai orangtua }\end{array}$ & 0.449 \\
\hline & MD15 & Memberitahu anak Anda mengapa mereka dihukum & 0.554 \\
\hline
\end{tabular}


Table 4

Fit Indexes of CFA Model

\begin{tabular}{ccccccccc}
\hline No & $\chi 2$ & $\mathrm{df}$ & $\chi 2 / \mathrm{df}$ & $\mathrm{CFI}$ & $\mathrm{GFI}$ & RMSEA & RMSR & Note \\
\hline 1 & 1267.650 & 349 & 3.6 & .82 & .94 & .08 & .06 & $\begin{array}{c}\text { Before deletion } \\
\text { and modification }\end{array}$ \\
2 & 577.750 & 206 & 2.8 & .90 & .96 & .06 & .04 & $\begin{array}{c}\text { After deletion } \\
\text { and modification }\end{array}$ \\
\hline
\end{tabular}

\section{Table 5}

Result of Construct Reliability in the Final MIPQ-Ind

\begin{tabular}{|c|c|c|c|c|c|}
\hline Dimensions & Indicators & $\lambda$ & $\lambda^{2}$ & $\mathrm{e}$ & CR \\
\hline \multirow{11}{*}{$\begin{array}{l}\text { Being in the moment } \\
\text { with child (BMC) }\end{array}$} & BIMC1 & 0.596 & 0.355 & 0.039 & \multirow[t]{11}{*}{.913} \\
\hline & BIMC2 & 0.569 & 0.323 & 0.047 & \\
\hline & BIMC3 & 0.652 & 0.424 & 0.039 & \\
\hline & BIMC4 & 0.607 & 0.369 & 0.037 & \\
\hline & BIMC5 & 0.660 & 0.436 & 0.038 & \\
\hline & BIMC6 & 0.640 & 0.409 & 0.040 & \\
\hline & BIMC7 & 0.631 & 0.399 & 0.044 & \\
\hline & BIMC8 & 0.661 & 0.437 & 0.041 & \\
\hline & BIMC9 & 0.711 & 0.505 & 0.037 & \\
\hline & BIMC10 & 0.681 & 0.463 & 0.038 & \\
\hline & BIMC11 & 0.733 & 0.537 & 0.039 & \\
\hline \multirow{11}{*}{$\begin{array}{l}\text { Mindful discipline } \\
\text { (MD) }\end{array}$} & MD2 & 0.553 & 0.306 & 0.044 & \multirow[t]{11}{*}{.906} \\
\hline & MD3 & 0.540 & 0.291 & 0.043 & \\
\hline & MD4 & 0.712 & 0.508 & 0.038 & \\
\hline & MD5 & 0.561 & 0.315 & 0.045 & \\
\hline & MD6 & 0.650 & 0.423 & 0.043 & \\
\hline & MD7 & 0.704 & 0.495 & 0.039 & \\
\hline & MD9 & 0.606 & 0.367 & 0.044 & \\
\hline & MD11 & 0.662 & 0.439 & 0.038 & \\
\hline & MD12 & 0.665 & 0.443 & 0.041 & \\
\hline & MD13 & 0.707 & 0.500 & 0.040 & \\
\hline & MD15 & 0.599 & 0.359 & 0.043 & \\
\hline
\end{tabular}

\section{Discussion}

The study aims to examine the validity of the Indonesian version of the MIPQ scores in parents of children aged 2-12 years. The validity test used was constructed validity with the EFA-CFA technique. This technique was employed by randomly dividing the sample into two so that EFA and CFA were applied to different samples. This is in accordance with the recommendations of Anderson and Magruder (2012) to avoid false discovery (type I error). Osborne (2014) also suggests that EFA and CFA tests on measurement 
can produce a logical model with a representative sample size and the right criteria in order to produce a conceptually acceptable solution. This data split technique and EFA-CFA application have also been employed in several previous studies, for example, those of Kumalasari et al. (2020), Ng (2013), Orue et al, (2020), Willmer et al. (2019). In the EFA test conducted for this study, the MSA and Bartlett test met the requirement, namely MSA = 0.95, and the Bartlett test was significant $(p<$ .001), so it can be said that MIPQ-Ind met the requirements for the EFA test (Hair et al., 2010). Two factors resulting from the oblique rotation were selected based on the criteria of Hair et al. (2010), who state that the selected factors should have eigenvalues $>1$ and factor loadings $\geq 0.3$. In addition, the Kaiser criterion (in Osborne, 2014) also indicates that an eigenvalue $>1$ means acceptable for a factor because an eigenvalue is the sum of the squares of factor loading in one column (the same factor). Osborne (2014) also states that in addition to the eigenvalue, factors can also be determined from the scree plot. The number of factors is determined by their position above the angle of the graph when the graph starts to slope. Therefore, based on Kaiser the criteria and scree plot images, the MIPQ-Ind dimension indicates a model that is in accordance with the original theory that MIPQ consists of two factors, and is in line with studies that have adapted MIPQ (Gördesli et al., 2018; Orue et al., 2020; Wu et al., 2019).

The reliability test of the EFA stage shows a good total reliability value and inter-item reliability with sufficient total items in each dimension. Furr (2011) states that a reliability value between 0.7 and 0.8 is considered sufficient for social research but is problematic if below 0.6 .
In the EFA model, the two recommended factors do not adequately explain the variance in the model. The results show that the total variance explained for the factors was only $41.7 \%$. A factor is considered good if it can explain at least $50 \%$ of the variance in the measurement (Beavers et al., 2013). However, the reliability values of the two factors are at a good level for social research. The insufficient variance explained in the scale can be caused by an error in measurement. Crocker and Algina (2006) state that there are two types of error in measurement, systematic and random. The systematic error occurs when the participants' characteristics or measurements do not match the construct being measured. It can reduce the usefulness of the test, but does not affect the consistency of the measurement results. On the other hand, random errors occur due to certain circumstances when taking measurements, such as distraction, the administrative process, the condition of the participants when completing the tests, etc. Such errors can affect the consistency and usability of the test. By considering cross-loadings, good reliability, and a strong correlation between factors in the scale, we presumed that systematic error has occurred in this study. This error can be related to the presence of other factors which explain the $58.3 \%$ variance in the MIPQ-Ind and the characteristics of the participants, who are not very diverse. Petty et al. (2003) states that a homogeneous sample can also cause low variance in factors.

Furthermore, in the CFA model, the fit index that the researcher used was $\chi 2 / \mathrm{df}<3-5$, GFI $>9$, CFI $>.9$, RMSEA $<.05$ or $<.06-0.8$, and RMSR $<.09$ (Hu \& Bentler, 1999). When the full MIPQ-Ind scale was employed in the first stage, the fit index 
did not meet the standard. Therefore, items that had a standardized factor loading < 0.5 were discarded. Costello and Osborne (2005); in social research, items considered quite good usually have loadings ranging between 0.4 and 0.7 . They can be kept if they have a loading $\geq 0.5$ and no cross-loading with other factors. Therefore, in the MIPQ-Ind, two items were discarded from the BMC dimension, namely BMC12 and BMC13, and four items were discarded from the MD dimension, namely MD1, MD8, MD10, MD14. We also modified items by adding relationship to covarians error of MD3-MD4, and BMC4-BMC5. As shown by the results of the study, after discarding and modifying the items, there was an improvement in the overall fit index. Eleven items remained in each dimension.

The validity test conducted was convergent validity, using internal structure analysis on the adapted MIPQ items. Furr (2011) states that this technique can be employed with CFA analysis. After obtaining a good fit index, analysis was conducted of the reliability construct, with the results showing that each dimension had a good internal structure. The results of the CFA also showed a strong correlation between the factors, thus supporting the findings of the EFA analysis with oblique rotation, which resulted in two factors being quite strongly correlated. This shows that the MIPQ consists of two unique attributes that represent the general construct of mindfulness in parenting. Nunally (in Azwar \& Ridho, 2013) states that a test should be composed of homogeneous items to measure a construct. However, according to Azwar and Ridho (2013) this is difficult to achieve when a test contains complex attributes or more than one domain. Costello and Osborne (2005) also state that it is difficult to define behavior in a single construct that is completely independent in social research. Therefore, the internal structure of MIPQ-Ind is in line with the original theory, which consists of two factors, namely being in the moment with the child, and the mindfulness discipline (McCaffrey et al., 2017).

McCaffrey et al. (2017) state that the factor of being in the moment with the child focuses more on children themselves and involves paying attention to them, and accepting and empathizing with them. On the other hand, the mindfulness discipline factor focuses more on the parenting practice of the parents, which includes nonreactive parenting and focuses on parenting goals. Based on the theory of McCaffrey et al. (2017), the dimension of being in the moment with the child was in this study termed 'keterlibatan pengasuh$a n^{\prime}$ and mindful discipline 'kesadaran pengasuhan'.

\section{Conclusion}

The study aimed to obtain evidence of the validity of the interpretation of the Indonesian version of the MIPQ scores in a population of parents with children aged 2-12 years in Indonesia. The results show that the MIPQ-Ind has two dimensions, namely being in the moment with the child (keterlibatan pengasuhan) and mindful discipline (kesadaran pengasuhan), with good convergent validity, as indicated by the fit index value and high construct reliability.

\section{Acknowledgments}

The research team would like to thank YARSI University and Konsorsium Psikologi Ilmiah Nusantara (KPIN) for supporting the research through research grants.] 


\section{References}

Ainsworth, M. D. S., Blehar, M. C., Waters, E., \& Wall, S. N. (2015). Patterns of attachment. Psychology Press. https://doi.org/10.4324/9780203758045

Anderson, M., \& Magruder, J. (2012). Learning from the Crowd: Regression discontinuity estimates of the effects of an online review database. The Economic Journal, 122(563), 957-989. https://doi.org/10.1111/j.1468-0297.2012.02512.x

Azwar, S., \& Ridho, A. (2013). Abilitas komposit dalam tes potensi. Jurnal Psikologi, 40(2), 127-142. https://doi.org/10.22146/jpsi.6972

Beavers, A. S., Lounsbury, J. W., Richards, J. K., Huck, S. W., Skolits, G. J., \& Esquivel, S. L. (2013). Practical considerations for using exploratory factor analysis in educational research. Practical Assessment, Research, and Evaluation, 18, 6. https://doi.org/10.7275/qv2q-rk76

Bögels, S. M., Hellemans, J., van Deursen, S., Römer, M., \& van der Meulen, R. (2014). Mindful parenting in mental health care: Effects on parental and child psychopathology, parental stress, parenting, coparenting, and marital functioning. Mindfulness, 5(5), 536-551. https://doi.org/10.1007/s12671-013-0209-7

Bornstein, L., \& Bornstein, M. H. (2014). Parenting styles and child social development. In Encyclopedia on Early Childhood Development (pp. 1-3).

Bronfenbrenner, U. (1979). The ecology of human development: Experiments by nature and design. Harvard University Press.

Calzada, E. J., Eyberg, S. M., Rich, B., \& Querido, J. G. (2004). Parenting disruptive preschoolers: Experiences of mothers and fathers. Journal of Abnormal Child Psychology, 32(2), 203-213. https://doi.org/10.1023/B:JACP.0000019771.43161.1c

Ciciolla, L., Gerstein, E. D., \& Crnic, K. A. (2014). Reciprocity among maternal distress, child behavior, and parenting: Transactional processes and early childhood risk. Journal of Clinical Child \& Adolescent Psychology, 43(5), 751-764. https://doi.org/10.1080/15374416.2013.812038

Coatsworth, J. D., Duncan, L. G., Nix, R. L., Greenberg, M. T., Gayles, J. G., Bamberger, K. T., Berrena, E., \& Demi, M. A. (2015). Integrating mindfulness with parent training: Effects of the mindfulnessenhanced strengthening families program. Developmental Psychology, 51(1), 26-35. https://doi.org/10.1037/a0038212

Cooklin, A. R., Giallo, R., \& Rose, N. (2012). Parental fatigue and parenting practices during early childhood: An Australian community survey. Child: Care, Health and Development, 38(5), 654664. https://doi.org/10.1111/j.1365-2214.2011.01333.x

Costello, A. B., \& Osborne, J. W. (2005). Best practices in exploratory factor analysis: Four recommendations for getting the most from your analysis.

Crocker, L. M., \& Algina, J. (2006). Introduction to classical and modern test theory. Cengage Learning.

Dahlan, T. H. (2016). Mindful parenting program in improving parenting skills of orphanage caregivers at Rumbela Muthmainnah Bandung. International Journal of Early Childhood Education and Care, 5, 57-64.

de Bruin, E. I., Zijlstra, B. J. H., Geurtzen, N., van Zundert, R. M. P., van de Weijer-Bergsma, E., Hartman, E. E., Nieuwesteeg, A. M., Duncan, L. G., \& Bögels, S. M. (2014). Mindful parenting assessed further: Psychometric properties of the Dutch Version of the Interpersonal Mindfulness in Parenting Scale (IM-P). Mindfulness, 5(2), 200-212. https://doi.org/10.1007/s12671-012-0168-4 
Duncan, L. G. (2007). Assessment of mindful parenting among parents of early adolescents: Development and validation of the Interpersonal Mindfulness in Parenting Scale. The Pennsylvania State University.

Duncan, L. G., Coatsworth, J. D., \& Greenberg, M. T. (2009a). A model of mindful parenting: Implications for parent-child relationships and prevention research. Clinical Child and Family Psychology Review, 12(3), 255-270. https://doi.org/10.1007/s10567-009-0046-3

Duncan, L. G., Coatsworth, J. D., \& Greenberg, M. T. (2009b). Pilot study to gauge acceptability of a mindfulness-based, family-focused preventive intervention. The Journal of Primary Prevention, 30(5), 605-618. https://doi.org/10.1007/s10935-009-0185-9

Furr, R. M. (2011). Scale construction and psychometrics for social and personality psychology. SAGE Publications Ltd. https://doi.org/10.4135/9781446287866

Gani, I. A., \& Kumalasari, D. (2019). Be mindful, less stress: Studi tentang mindful parenting dan stres pengasuhan pada ibu dari anak usia middle childhood di Jakarta. Jurnal Psikologi, 15(2), 98107. https://doi.org/10.24014/jp.v15i2.7744

Geurtzen, N., Scholte, R. H. J, Engels, R. C. M. E., Tak, Y. R., \& van Zundert, R. M. P. (2015). Association between mindful parenting and adolescents' internalizing problems: Non-judgmental acceptance of parenting as core element. Journal of Child and Family Studies, 24(4), 1117-1128. https://doi.org/10.1007/s10826-014-9920-9

Gördesli, M. A., Arslan, R., Çekici, F., Sünbül, Z. A., \& Malkoç, A. (2018). The psychometric properties of Mindfulness in Parenting Questionnaire (MIPQ) in Turkish sample. European Journal of Education Studies, 5(5), 175-188. https://doi.org/10.5281/zenodo.1477467

Gouveia, M. J., Carona, C., Canavarro, M. C., \& Moreira, H. (2016). Self-compassion and dispositional mindfulness are associated with parenting styles and parenting stress: The mediating role of mindful parenting. Mindfulness, 7(3), 700-712. https://doi.org/10.1007/s12671-016-0507-y

Hair, J. F., Black, B., Black, W. C., Babin, B. J., \& Anderson, R. E. (2010). Multivariate Data Analysis: Global Edition (7th ed.). Pearson Education.

Hu, L., \& Bentler, P. M. (1999). Cutoff criteria for fit indexes in covariance structure analysis: Conventional criteria versus new alternatives. Structural Equation Modeling: A Multidisciplinary Journal, 6(1), 1-55. https://doi.org/10.1080/10705519909540118

Kumalasari, D., Luthfiyani, N. A., \& Grasiawaty, N. (2020). Analisis faktor adaptasi instrumen resiliensi akademik versi Indonesia: Pendekatan eksploratori dan konfirmatori. JPPP - Jurnal Penelitian Dan Pengukuran Psikologi, 9(2), 84-95. https://doi.org/10.21009/JPPP.092.06

McCaffrey, S. (2015). Mindfulness in Parenting Questionnaire (MIPQ): Development and validation of a measure of mindful parenting. Nova Southeastern University.

McCaffrey, S., Reitman, D., \& Black, R. (2017). Mindfulness in Parenting Questionnaire (MIPQ): Development and validation of a measure of mindful parenting. Mindfulness, 8(1), 232-246. https://doi.org/10.1007/s12671-016-0596-7

Medeiros, C., Gouveia, M. J., Canavarro, M. C., \& Moreira, H. (2016). The indirect effect of the mindful parenting of mothers and fathers on the child's perceived well-being through the child's attachment to parents. Mindfulness, 7(4), 916-927. https://doi.org/10.1007/s12671-016-0530-z

Neece, C. L., Green, S. A., \& Baker, B. L. (2012). Parenting stress and child behavior problems: A transactional relationship across time. American Journal on Intellectual and Developmental Disabilities, 117(1), 48-66. https://doi.org/10.1352/1944-7558-117.1.48 
$\mathrm{Ng}$, S. (2013). Validation of the 10-item Chinese perceived stress scale in elderly service workers: onefactor versus two-factor structure. BMC Psychology, 1(1), 9. https://doi.org/10.1186/2050-7283-1-9

Orue, I., Calvete, E., González, L. F., Odriozola, J. G., Colomer, E. R., \& Cortázar, N. (2020). A Spanish adaptation of the mindfulness in parenting questionnaire. Psicothema, 32(1), 130-137. https://doi.org/10.7334/psicothema2019.260

Osborne, J. W. (2014). Best practices in exploratory factor analysis. Createspace publishing.

Parent, J., McKee, L. G., N. Rough, J., \& Forehand, R. (2016). The association of parent mindfulness with parenting and youth psychopathology across three developmental stages. Journal of Abnormal Child Psychology, 44(1), 191-202. https://doi.org/10.1007/s10802-015-9978-x

Petty, R. E., Fabrigar, L. R., \& Wegener, D. T. (2003). Emotional factors in attitudes and persuasion. In R. J. Davidson, K. R. Scherer, \& H. H. Goldsmith (Eds.), Handbook of affective sciences (pp. 752-772). Oxford University Press.

Razza, R. A., \& Raymond, K. (2013). Associations among maternal behavior, delay of gratification, and school readiness across the early childhood years. Social Development, 22(1), 180-196. https://doi.org/10.1111/j.1467-9507.2012.00665.x

Reynolds, D. (2003). Mindful Parenting: A group approach to enhancing reflective capacity in parents and infants. Journal of Child Psychotherapy, 29(3), 357-374. https://doi.org/10.1080/00754170310001625413

Rosyada, A., \& Ramadhianti, A. (2019). Applying positive language in mindful parenting: A means of building positive character in children. ASEAN Journal of Community Engagement, 3(2), 175195. https://doi.org/10.7454/ajce.v3i2.1058

Saraswati, W., \& Febriani, Z. (2018). Hubungan antara mindful parenting dengan gaya pengasuhan pada ibu yang memiliki anak usia 3-6 tahun. Jurnal Psikogenesis, 6(2), 214-222. https://doi.org/10.24854/jps.v6i2.704

Singh, N. N., Lancioni, G. E., Winton, A. S. W., Singh, J., Curtis, W. J., Wahler, R. G., \& McAleavey, K. M. (2007). Mindful parenting decreases aggression and increases social behavior in children with developmental disabilities. Behavior Modification, 31(6), 749-771. https://doi.org/10.1177/ 0145445507300924

Sofyan, I. (2019). Mindful Parenting: Strategi Membangun Pengasuhan Positif dalam Keluarga. Journal of Early Childhood Care and Education, 1(2), 41-47. https://doi.org/10.26555/jecce.v1i2.241

Utami, A. T., Khasanah, A. N., Mubarak, A., \& Sartika, S. (2020). Mindful parenting: Study on parents of preschool children. Proceedings of the 2nd Social and Humaniora Research Symposium (SoRes 2019), 380-382. https://doi.org/10.2991/assehr.k.200225.080

Waylen, A., \& Stewart-Brown, S. (2010). Factors influencing parenting in early childhood: A prospective longitudinal study focusing on change. Child: Care, Health and Development, 36(2), 198-207. https://doi.org/10.1111/j.1365-2214.2009.01037.x

Williams, K. L., \& Wahler, R. G. (2010). Are mindful parents more authoritative and less authoritarian? An analysis of clinic-referred mothers. Journal of Child and Family Studies, 19(2), 230-235. https://doi.org/10.1007/s10826-009-9309-3

Willmer, M., Westerberg Jacobson, J., \& Lindberg, M. (2019). Exploratory and confirmatory factor analysis of the 9-Item Utrecht Work Engagement Scale in a multi-occupational female sample: A cross-sectional study. Frontiers in Psychology, 10, 2771. https://doi.org/10.3389/fpsyg.2019.02771 
Wu, L., Buchanan, H., Zhao, Y., Wang, P., Zhan, Z., Zhao, B., \& Fan, B. (2019). Translation and validation of a Chinese Version of the Mindfulness in Parenting Questionnaire (MIPQ). Frontiers in Psychology, 10, 1-13. https://doi.org/10.3389/fpsyg.2019.01847

Zaenab, S., \& Indryanai, D. D. I. R. (2020). Mindful parenting based on development brain children in PAUD Fortune. Proceedings of the 3rd International Conference on Learning Innovation and Quality Education (ICLIQE 2019), 97-105. https://doi.org/10.2991/assehr.k.200129.013 
This page has been intentionally left blank. 